\title{
Vulvar Eccrine Porocarcinoma
}

National Cancer Institute

\section{Source}

National Cancer Institute. Vulvar Eccrine Porocarcinoma. NCI Thesaurus. Code C40306.

An eccrine porocarcinoma that arises from the sweat glands in the vulva. 